\title{
DAMAGE ACTIONS UNDER SECTION 1983 FOR ILLEGAL SEARCHES AND SEIZURES: RECONSIDERING THE APPLICABILITY OF COLLATERAL ESTOPPEL
}

An individual who alleges that police officers violated his fourth amendment rights by an illegal search and seizure has a cause of action for damages against the officers under 42 U.S.C. $\S 1983 .^{1}$ The doctrine of collateral estoppel, however, will often deny a defendant in a state criminal prosecution the opportunity to litigate his section 1983 claim in a federal forum. ${ }^{2}$ Most federal courts have held that a state criminal

1. 42 U.S.C. $\$ 1983$ (1976). The statute, originally enacted as section 1 of the Civil Rights Act of 1871 , ch. $22, \S 1,17$ Stat. 13 (1871), provides:

Every person, who under color of any statute, ordinance, regulation, custorn, or usage, of any State or Territory, subjects, or causes to be subjected, any citizen of the United States or other person within the jurisdiction thereof to the deprivation of any rights, privileges, or immunities secured by the Constitution and laws, shall be liable to the other party mjured in an action at law, suit in equity, or other proper proceeding for redress.

In the case of an illegal search and seizure, the plaintiff is, of course, alleging a violation of his fourth amendment rights as applied to the states through the fourteenth ainendinent. The defendant police officer in a section 1983 case is not strictly or absolutely liable for the violation. $\mathrm{He}$ enjoys a qualified immunity. To succeed, the plaintiff unust show that the officer acted without good faith and without reasonable belief that probable cause existed for the search or for the arrest. Pierson v. Ray, 386 U.S. 547, 555-57 (1967).

A section 1983 plaintiff is apparently entitled to recover only nouninal danages absent proof of actual injury. Carey v. Piphus, 435 U.S. 247 (1978). In Carey the Court indicated that the common law of tort will govern the dannages recoverable in section 1983 actions. Carey, however, involved a denial of procedural due process rather than a denial of fourth amendment rights. It is not certain, therefore, whether the requirement of proof of actual injury will be extended to an action involving a violation of fourth amendment rights.

2. The following sequence of hypothetical events illustrates a situation in which collateral estoppel frequently would be applied: the local police enter a suspect's houne in violation of the fourth amendment, make a thorough search, and seize certain itens to be used as evidence against the suspect in a state criminal proceeding. At trial, the defendant moves to suppress the evidence, alleging that the search and seizure violated rights secured to hin by the fourth amendunent to the United States Constitution. The defendant bases his motion to suppress on the exclusionary rule, extended to the states in Mapp v. Ohio, 367 U.S. 643 (1961). See generally Traynor, Mapp v. Ohio at Large in the Fifty States, 1962 DuKE L.J. 319. The issue is litigated in a suppression lrearing and the court denies the motion to suppress. The evidence, adınitted at trial, is instrumental in gaining a conviction for the state. Subsequently, the defendant files a civil action for dainages in federal district court pursuant to section 1983, alleging that the police violated his constitutional 
conviction estops the plaintiff in a subsequent civil rights action from litigating issues that were actually litigated and necessarily resolved against him in the prior criminal proceeding. ${ }^{3}$ Thus, when a defendant has unsuccessfully litigated fourth amendment issues in a state court suppression liearing, most federal courts will effectively preclude him from bringing a subsequent section 1983 civil damages action.

Many of the cases applying collateral estoppel to the section 1983 coinplaint of a convicted offender were decided prior to the Supreme Court's decision in Stone v. Powell. ${ }^{4}$ The courts assumed or expressly stated that an alternate route to federal court was available to the litigant through federal liabeas corpus. ${ }^{5}$ In Stone, however, the Court lield that federal liabeas corpus relief need not be available when fourtl ainendinent issues liave been previously litigated in a state tribunal. ${ }^{6}$ If a prior state adjudication of federal constitutional issues wcre to preclude a subsequent section 1983 action in federal district court, many plaintiffs would therefore be denied access to any federal forum.

The Court of Appeals for the Eiglith Circuit, in McCurry v. Allen, ${ }^{7}$ recently ruled that the interest in providing a federal forum for the litigation of fourtli ainendment claims under section 1983 overrides the interests and policies whicl1 would otherwise warrant the apphication of collateral estoppel. Under $M c$ Curry, therefore, an individual who has had an opportunity to challenge the constitutionality of a search and seizure in a state suppression liearing can still bring a section 1983 action in federal court.

This Note will examme the doctrine of collateral estoppel as applied by the federal courts to section 1983 actions. The Note will then

rights by conducting an illegal search and seizure. The section 1983 defendants thereupon interpose collateral estoppel as a defense to the plaintiff's action by moving for suminary judgment. The court grants the motion upon a showing that the issue of the constitutionality of the search and seizure was fully litigated in the state suppression hearing and was there determined adversely to the section 1983 plaintiff.

3. See, e.g., Martin v. Delcambre, 578 F.2d 1164 (5th Cir. 1978) (a plaintiff is collaterally estopped as long as his state conviction was valid); Mastracchio v. Ricci, 498 F.2d 1257 (Ist Cir. 1974) (application of collateral estoppel to section 1983 actions is supported by the overwhelming weight of authority), cert. denied, 420 U.S. 909 (1975); Zurek v. Woodbury, 446 F. Supp. 1149 (N.D. III. 1978) (a state criminal conviction will estop the plaintiff in a civil rights action from litigating issues necessarily resolved agamst him in the prior criminal proceeding); Smith v. Sinclair, 424 F. Supp. I108 (W.D. Okla. 1976) (the Civil Rights Act was not designed to sponsor career litigants); Palma v. Powers, 295 F. Supp. 924 (N.D. Ill. 1969) (collateral estoppel applied).

4. 428 U.S. 465 (1976).

5. See note 124 infra and cases cited therein.

6. See text accompanying notes $118-22$ infra.

7. 606 F.2d 795 (8th Cir. 1979), cert. granted, 100 S. Ct. 1012 (1980) (No. 79-935). McCurry has been followed by the Court of Appeals for the Nintl Circuit in Johnson v. Mateer, 625 F.2d 240 (9th Cir. 1980). 
analyze the Eighth Circuit's decision in $M c C u r r y,{ }^{8}$ which rejects the doctrine of collateral estoppel in this context. Finally, the Note will discuss four reasons for permittmg plaintiffs to bring section 1983 actions free from the bar of collateral estoppel. First, the Congress that enacted section 1983 clearly contemplated that the federal courts would be the primary guardians of rights protected by that legislation. ${ }^{9}$ In refusing to apply collateral estoppel, the McCurry court acknowledged the special role that the federal courts play in protecting civil rights. ${ }^{10}$ While the need to interpose federal judicial power between the citizens and the state governments is not as compelling today as when the Forty-second Congress enacted section 1983,"11 institutional differences between the federal and state judicial systems still necessitate the preservation of a federal forum. Second, permitting a section 1983 action for damages is consistent with the pohicy of comity. ${ }^{12}$ A subsequent section 1983 action brought in federal court does not imply disrespect for the prior conviction im a state court. Third, the removal im Stone $v$. Powell ${ }^{13}$ of the federal habeas corpus remedy for fourth amendment violations compels the conclusion that access to the federal courts under section 1983 must not be restricted by the rules of collateral estoppel. The McCurry court refused to apply collateral estoppel because, inter alia, federal habeas corpus was unavailable to the criminal defendant. ${ }^{14}$ Finally, the necessity for an effective reinedy for fourth amendment violations requires that section 1983 actions be unhampered by the pitfalls of collateral estoppel. ${ }^{15}$ The application of collateral estoppel to section 1983 actions that follow state court proceedings negates the purpose of section 1983: to provide an effective federal remedy for the violation of federal constitutional rights.

\section{Collateral Estoppel in the Section 1983 Context}

Collateral estoppel, or issue preclusion, ${ }^{16}$ comprises a subset of the principles more generally denominated "res judicata." 17 Three ele-

8. 606 F.2d 795 (8th Cir. 1979), cert. granted, 100 S. Ct. 1012 (1980) (No. 79-935).

9. See text accompanying notes $51-68 \mathrm{infra}$.

10. 606 F.2d at 799 .

11. See note 69 infro and accompanymg text.

12. Considerations of comity have often been used to justify the application of collateral estoppel to section 1983 actious that follow state proceedings. See, e.g., Fernandez v. Trias Monge, 586 F.2d 848, 856 (1st Cir. 1978). See text accompanying notes 87-111 infra.

13. 428 U.S. 465 (1976). See text accoinpanying notes 112-43 infra.

14. 606 F.2d at 799 .

15. See text accompanying notes 144-68 infra.

16. The ResTatement (SECOND) OF JudGmients $\$ 74$ (Tent. Draft No. 3, 1976) refers to res judicata as "claim preclusion" and collateral estoppel as "issue preclusion."

17. The principle of res judicata ineans that a judgment in an action, 
ments are necessary to support a defense of collateral estoppel. First, the fact or question im issue must have been directly adjudicated or necessarily determmed in a proceeding in which a final judginent on the merits was rendered. Second, those issues a party seeks to relitigate must be identical to those adjudicated in the prior action. Third, the party agaimst whom the defense is asserted must have been a party, or in privity with a party, to the prior action. ${ }^{18}$

The basic premise supporting the doctrine of collateral estoppel is that litigation must eventually end. Both society and litigants demand that the judicial systein operate efficiently, that the integrity of judgments not be undermined, that primciples of coinity be respected, and that litigants not be harrassed by repetitive and vexatious lawsuits. ${ }^{19}$ Collateral estoppel is, however, a matter of policy; courts make exceptions when there are superior countervailing policy considerations. ${ }^{20}$

\section{A. Collateral Estoppel in Section 1983 Actions.}

Although the rules of res judicata and collateral estoppel are essentially judge-made, the concept itself is codified in section 1738 of the Judicial Code:21 "The . . . judicial proceedings of any . . . State . . . shall have the saine full faith and credit in every court within the United States . . . as they have by law or usage in the courts of such State . . from which they are taken."22 The statute requires the federal courts to apply the res judicata rules of the state in which the prior judgment was rendered, rather than a federal common law of res judicata. Thus, the preclusion of inany claiuns under section 1983 for violations of constitutional rights inay be supported not only by the weight of judicial authority, ${ }^{23}$ but also by the mandate of section 1738 of the

if rendered upon the merits, constitutes an absolute bar to a subsequent action. It is a finality as to the claim or demand in controversy, concluding parties and those in privity with them, not only as to every matter which was offered and received to sustain or defeat the claim or demand, but as to any other admissible unatter which unight have been offered for that purpose.

Cromwell v. County of Sac, 94 U.S. 351, 352 (1877). Collateral estoppel, however, operates so that in a second action between the same parties, but on a different cause of action, "the judgment in the prior action operates as an estoppel only as to those matters in issue or points controverted, upon the determination of which the finding or verdict was rendered." Id. at 353.

18. E.g., Palma v. Powers, 295 F. Supp. 924, 933-34 (N.D. Ill. 1969).

I9. See Vestal, Rationale of Preclusion, 9 ST. Louls U.L.J. 29, 31 (1964); Note, Developments in the Law of Res Judicata, 65 HARV. L. REv. 818, 820 (1952); Comment, The Collateral Estoppel Effect of State Criminal Convictions in Section 1983 Actions, 1975 U. ILL. L.F. 95, 96.

20. See Vestal, supra note 19, at 54-55.

2I. 28 U.S.C. $\S 1738$ (1976).

22. Id. The statute's requirement extends to the federal courts. See Huron Holding Corp. v. Lincoln Mine Operating Co., 312 U.S. 183, 193 (1941).

23. See, e.g., Martin v. Delcambre, 578 F.2d I164 (5th Cir. 1978) (a plaintiff is collaterally estopped as long as his state conviction is valid); Wiggins v. Murphy, 576 F.2d 572 (4th Cir. 1978) 
Judicial Code. ${ }^{24}$

In the context of fourth amendment claims, a ruling by the court on a suppression motion, followed by a conviction, is a final judgment for the purposes of collateral estoppel. ${ }^{25}$ Hence, many federal courts have applied collateral estoppel to section 1983 actions that followed state criminal proceedings. ${ }^{26}$ These courts have accepted the proposition that full litigation of an issue in a state criminal proceeding forecloses subsequent relitigation of the issue in a civil proceeding when resolution of the issue was essential to the conviction. ${ }^{27}$

Section 1738 collateral estoppel rules, however, have not always been so rigidly applied. Some federal courts have recognized that different well-defined federal policies may compete with and prevail over the principles underlying section $1738 .{ }^{28}$ The pohicy of adjudicating a section 1983 cause of action in a federal forum is one such policy. Various federal courts have therefore narrowly construed the requirements of collateral estoppel im order to provide a federal forum to the section 1983 litigant when possible. ${ }^{29}$

Courts limitimg the application of section 1738 have generally construed literally the requirement that issues be actually hitigated and necessarily determined. These courts hold that an unreversed state

(res judicata precludes a subsequent federal civil rights action), cert. denied, 439 U.S. 1091 (1979); Rimmer v. Fayetteville Police Dep't, 567 F.2d 273 (4th Cir. 1977) (section 1983 warrants no departure from collateral estoppel); Mastracchio v. Ricci, 498 F.2d 1257 (Ist Cir. 1974) (application of collateral estoppel is supported by the weight of authority), cert. denied, 420 U.S. 909 (1975); Thistlethwaite v. City of New York, 497 F.2d 339 (2d Cir.) (collateral estoppel applied against criminal defendant), cert. denied, 419 U.S. 1093 (1974).

24. At least one commentator has reached this conclusion. See Currie, Res Judicata: The Neglected Defense, 45 U. ChI. L. Rev. 317, $327-33$ (1978).

25. See, e.g., Rodriguez v. Beame, 423 F. Supp. 906, 908 (S.D.N.Y. 1976).

26. See cases cited in note 23 supra.

27. See, e.g., Rimmer v. Fayetteville Police Dep't, 567 F.2d 273, 276 (4th Cir. 1977); Thistlethwaite v. City of New York, 497 F.2d 339, 342 (2d Cir.), cert. denied, 419 U.S. 1093 (1974). In Thistlethwaite, the Court of Appeals for the Second Circuit held that when a first amendment issue had been determined against the section 1983 plaintiffs in a state criminal trial, res judicata barred the plaintiffs from relitigating the issue in a civil rights suit in federal court. See also Smith v. Sinclair, 424 F. Supp. 1108, 1111 (W.D. Okla. 1976) (citing Thistlethwaite).

28. See Mitchell v. National Broadcasting Co., 553 F.2d 265, 274 (2d Cir. 1977) (plaintiffs section 1981 claim barred by res judicata); American Mannex Corp. v. Rozands, 462 F.2d 688, 690 \& n.1 (5th Cir. 1971) (res judicata applied), cert. denied, 409 U.S. 1040 (1972); Kremer v. Chemical Constr. Corp., 464 F. Supp. 468, 472 (S.D.N.Y. 1978) (res judicata not applied to title VII action). See also Lyons v. Westinghouse Elec. Corp., 222 F.2d 184, 189 (2d Cir.) (section 1738 will not be applied if the question involves a matter within the exclusive jurisdiction of the federal courts), cert. denied, 350 U.S. 825 (1955); Note, Res Judicata: Exclusive Federal Jurisdiction and the Effect of Prior State-Court Determinations, 53 VA. L. REv. 1360 (1967).

29. See, e.g., Ornstem v. Regan, 574 F.2d 115, 117 (2d Cir. 1978) (refusing to apply res judicata to a section 1983 action). See text accoinpanying notes 30-35 infra. 
conviction does not by itself require dismissal of a section 1983 claim. ${ }^{30}$ The federal court must be able to determine clearly from the record that the same questions were addressed directly and were resolved in the prior action. ${ }^{31}$ At least one district court has held that if reasonable doubt exists as to what issues were decided in the prior action, such doubt should be resolved by not precluding the plaintiff from litigating thein in the section 1983 action. $^{32}$ For example, a conviction for resisting arrest does not estabhish that the police officers had probable cause to make the arrest. It has thus been held that collateral estoppel does not preclude a section 1983 action based upon fourth amendment claims and allegations that the police used excessive force in making the arrest. ${ }^{33}$

In Brubaker v. King ${ }^{34}$ the Court of Appeals for the Seventh Circuit construed very narrowly the "actually litigated" requirement of collateral estoppel. The court concluded that the issue to be determined at a suppression hearing in a state criminal trial (i.e., whether the search violated the fourth amendment) was not the same issue that a section 1983 action presents (i.e., whether there was a good faith, reasonable belief that the search was conducted with probable cause). By definition, therefore, collateral estoppel did not apply because the underlying issue in the section 1983 action had not been previously litigated in the state court. ${ }^{35}$ This approach does not, however, prevent collateral estoppel from barring a subsequent section 1983 action founded on a fourth amendment claim. The problem with this approach is that a finding by a state tribunal that a police officer inade a search and seizure with probable cause-an objective determination-usually includes an imphicit finding that the officer subjectively acted in good faith and with the reasonable behef that probable cause existed at the time of the search and seizure. ${ }^{36}$ Consequently, when a search and seizure is challenged in a section 1983 action in federal district court, the issue of good faith and reasonable behef will have been "actually

30. See, e.g., Mulligan v. Schlachter, 389 F.2d 231, 232-33 (6th Cir. 1968). See also cases cited in note 33 infra.

31. See Ornstein v. Regan, 574 F.2d 115, 117 (2d Cir. 1978) (limits on disability retirement benefits); Winters v. Lavine, 574 F.2d 46, 57 (2d Cir. 1978) (denial of Medicaid benefits); Ames v. Vavreck, 356 F. Supp. 931, 941 (D. Minn. 1973) (fourth amendment violation).

32. Kauffman v. Moss, 420 F.2d 1270, 1274 (3d Cir.), cert. denied, 400 U.S. 846 (1970).

33. See Williains v. Liberty, 461 F.2d 325 (7th Cir. 1972); Spencer v. Town of Westerly, R.l., 430 F. Supp. 636 (D.R.I. 1977); Clark v. Illinois, 415 F. Supp. 149 (N.D. Ill. 1976); Wecht v. Marsteller, 363 F. Supp. 1183 (W.D. Pa. 1973).

34. 505 F.2d 534 (7th Cir. 1974).

35. Id. at $536-38$.

36. McCurry v. Allen, 606 F.2d 795, 798 n.10 (8th Cir. 1979), cert. granted, 100 S. Ct. 1012 (1980) (No. 79-935). 
litigated" and "necessarily determined" in the state suppression hearing. A court applying normal collateral estoppel principles will be compelled to dismiss the section 1983 action because all pertinent issues will have been litigated and determined in the prior action.

\section{B. Collateral Estoppel Rejected in McCurry v. Allen.}

The Court of Appeals for the Eighth Circuit, in McCurry v. Allen, ${ }^{37}$ avoided a disingenuously narrow construction of collateral estoppel principles. Instead, the court simply held that collateral estoppel did not bar a defendant who had been convicted in a state criminal prosecution froin subsequently bringing a section 1983 action, even though he had already litigated his fourth amendment claim in a suppression hearing. ${ }^{38}$

In McCurry, six undercover police officers went to McCurry's house to purchase heroin. The police officers designated to make the buy asked McCurry if he was willing to sell them heroin. McCurry went back into his liome; when he returned to the door he began shooting at the police officers. After McCurry surrendered, the police rushed into the house to check for additional persons. Sometime later, an officer searched McCurry's home and found heroin inside several drawers, alnong soine tires, and also in plain view in several locations. Prior to trial, McCurry moved to suppress all this evidence. The trial court, after a suppression liearing, granted the motion to suppress the evidence discovered in drawers and among the tires, but denied the motion as to the evidence found in plain view. McCurry was convicted at trial on one count of illegal possession of heroin and on two counts of assault with intent to kill. ${ }^{39}$

After his conviction, McCurry filed a section 1983 claim for $\$ 1,000,000$ in damages against the arresting police officers. McCurry alleged that the police had conspired to conduct an illegal search of his home, that the lome had been illegally searched, and that certain police officers had assaulted him upon arrest. The defendant police officers moved for summary judgment, and the district court granted their motion on the ground that McCurry had fully litigated the constitutionality of the search of his house in his state suppression hearing and the issue had been determined adversely to him on the merits. The

37. 606 F.2d 795 (8th Cir. 1979), cert. granted, 100 S. Ct. 1012 (1980) (No. 79-935).

38. 606 F.2d at 797-99.

39. Id. at 796 . 
trial court thus held that McCurry was collaterally estopped from asserting his claim in the subsequent damage action. ${ }^{40}$

The Court of Appeals for the Eighth Circuit reversed. Initially, the court noted that the district court failed to address McCurry's allegation that he had been assaulted by a police officer. ${ }^{41}$ That this claim had not been addressed by the court below alone constituted grounds for reversal. More significantly, however, the court of appeals acknowledged that although the search and seizure aspect of the claim was "essentially the same claim that was litigated at the suppression hearing," 42 this identity of issues did not require "the conclusion that appellant's $\S 1983$ claim is barred by collateral estoppel." 43 The court reasoned that "because of the special role of federal courts im protectimg civil rights, . . . and because habeas corpus is now unavailable to appellant [under Stone v. Powell ${ }^{44}$ ], it is our duty to consider fully, unencumbered by the doctrine of collateral estoppel, appellant's $\S 1983$ claims."45 Despite that decision, however, the court then decided to abstain from hearing the case under the rule in Younger v. Harris ${ }^{46}$ until direct appeal of McCurry's claim had been completed in the Missouri courts. ${ }^{47}$

The rejection of collateral estoppel in McCurry is a drastic departure from prior law. 48 Nevertheless, as the McCurry court noted, the

40. This Court will grant defendants' motion on the grounds that the only issue in the instant lawsuit-whether the entrance into plaintiffs home and the resulting search was lawful - was litigated on the merits at his crininal trial in state court and determined adversely to his position. Therefore, plaintiff may not collaterally attack that determination and he is collaterally estopped from relitigating the constitutionality of the search. McCurry v. Allen, 466 F. Supp. 514, 515-16 (E.D. Mo. 1978), rev'd, 606 F.2d 795 (8th Cir. 1979), cert. granted, 100 S. Ct. 1012 (1980) (No. 79-935).

41. 606 F.2d at 797.

42. $I d$.

43. Id.

44. 428 U.S. 465 (1976). The Stone Court held that a prisoner's "opportunity for full and fair litigation" of his fourth amendment claim in state court foreclosed his use of the remedy of federal habeas corpus. Id. at 482.

45. 606 F.2d at 799 (citations omitted).

46. 401 U.S. 37 (1971). In Younger the Supreme Court held that a federal court is prohibited, absent extraordinary circuunstances, from issuing an injunction that would stay a pending state criminal proceeding for the purpose of litigating federal constitutional issues.

47. 606 F.2d at 799. See note 101 infra.

48. The United States Supreme Court has granted certiorari. 100 S. Ct. 1012 (1980) (No. 79. 935). The Court has not expressly decided whether collateral estoppel principles must be applied to section 1983 claims. Johnson v. Mateer, 625 F.2d 240, 243 (9th Cir. 1980). In Preiser v. Rodriguez, 411 U.S. 475 (1973), a state prisoner brought a section 1983 claim alleging that his constitutional rights had been violated by the denial of "good time" credits by state officials. The Court held that the plaintiff's proper remedy was habeas corpus. In distinguishing the habeas remedy from a civil rights action, the Court stated that "res judicata has been held [by lower courts] to be fully applicable to a civil rights action brought under $\$ 1983$." Id. at 497 . The Court has been equally noncommittal in other decisions. In Huffman v. Pursue, Ltd., 420 U.S. 592, 606 n.18 (1975), the Court stated, "We in no way intend to suggest that . . . the normal rules of res judicata 
judicially created doctrine of collateral estoppel must be limited so that the section 1983 remedy does not become meaningless. In nearly all cases in which a defendant has had the constitutionahty of a search and seizure determined in a state court suppression hearing, collateral estoppel would preclude a subsequent section 1983 damages action in federal court. The Court of Appeals for the Ninth Circuit has observed:

[I] $\mathrm{f}$ a successful state prosecution, based upon the use of information obtained by violating the defendant's constitutional rights, could bar a civil rights action against the police for violating his rights, either by analogy to the law of inalicious prosecution or on theories of res judicata or estoppel by judgement, the Civil Rights Act would, in inany cases, be a dead letter. ${ }^{49}$

Thus, to inaintain the vitality of section 1983 as a federal remedy for the redress of fourth amendment violations, an exception to the operation of normal collateral estoppel rules must be made. Congress created the remedy as a means of protectimg federal constitutional rights from violations by state officials. Simply because a state trial court has concluded that a search and seizure conducted by state officials does not violate the fourth amendment does not compel the conclusion that a section 1983 action in federal court should not be permitted. Indeed, Congress enacted section 1983 to provide a federal remedy for situations in which state judiciaries would not enforce or would madequately enforce federal constitutional rights. The fourth amendment claimant has no access to a federal forum via habeas corpus in these circumstances. ${ }^{50}$ It is therefore imperative to preserve a federal forum for damage actions pursuant to section 1983 in order to vimdicate fourth amendment rights.

and judicial estoppel do not operate to bar relitigation in actions under 42 U.S.C. $\$ 1983$ of federal issues arising in state court proceedings." In Wolff v. McDonnell, 418 U.S. 539, 554 n.12 (1974) the Court stated, "One would anticipate that normaI principles of res judicata would apply in such circuunstances."

49. Ney v. California, 439 F.2d 1285, 1288 (9th Cir. 1971). In Ney the Court of Appeals for the Ninth Circuit dealt with an allegation that a state prisoner had been denied his Miranda rights. The issue had not been litigated in the same court. After his conviction, the defendant brought a section 1983 action against the arresting officers. The court refused to bar the claim on the ground of res judicata although the constitutional issue might have been raised in the state proceeding. Using the precedent of Ney and $M c C u r r y$, the Ninth Circuit has recently held that a section 1983 plaintiff whose cause of action is based upon an allegedly illegal search and seizure will not be barred by collateral estoppel where the fourth amendment issue was previously decided in a state court suppression liearing. Johnson v. Mateer, 625 F.2d 240 (9th Cir. 1980).

50. See Stone v. Powell, 428 U.S. 465, $481-82$ (1976). 


\section{Federal Courts as the Preferred Forum for Section 1983 ACTIONS}

\section{A. The Legislative Purpose of Section 1983.}

One of the two reasons ${ }^{51}$ the McCurry court relied upon in refusing to bar the section 1983 claim was that federal courts play a special role in the protection of civil rights. ${ }^{52}$ At least one Supreme Court Justice believes that section 1983 is one of the "principal foundations" upon which Congress, after the Civil War, established the federal court systein as the primary guardian of federal constitutional rights. ${ }^{53}$

The McCurry panel relied upon the Supreme Court's decision in Mitchum v. Foster ${ }^{54}$ in finding that section 1983 established the lower federal courts as the primary guardians of rights secured by the Constitution. The Court stated in Mitchum that section 1983 interposed the federal courts between the states and the people to prevent the demial of individual constitutional liberties by the action of state officials. ${ }^{55}$ In Mitchum the Court held that a suit in equity to redress the deprivation of federal constitutional rights under section 1983 is an "expressly authorized" exception to the Anti-Injunction Act, ${ }^{56}$ which limits the authority of federal courts to stay state court proceedings. ${ }^{57}$ The Court explained that "exceptions must be made to [the Anti-Injunction Act's] blanket prohibition if the import and purpose of other Acts of Congress are to be given their intended scope."58 After lengthy discussion of the legislative history of section 1983, the Court concluded that the Civil Rights Act "opened the federal courts to private citizens, offering a

51. The second basis for the court's decision was the unavailability of habeas corpus under Stone v. Powell, 428 U.S. 465 (1976). 606 F.2d at 799.

52. 606 F.2d at 799.

53. Perez v. Ledesma, 401 U.S. 82, 106-07 (I971) (Brennan, J., concurring and dissenting). The other foundations referred to by Justice Brennan are the federal review of action by state officials, as permitted by Ex Parte Young, 209 U.S. 123 (1908), and the grant to the federal courts of federal question jurisdiction by the Judiciary Act of 1875,28 U.S.C. $\$ 1331$ (1976), 401 U.S. at 106-07.

54. 407 U.S. 225 (I972).

55. Id. at 242. See generally Averitt, Federal Section 1983 Actions After State Court Judgment, 44 U. Colo. L. Rev. 19I, 210 (1972); Theis, Res Judicata in Civil Rights Act Cases, 70 Nw. U.L. Rev. 859, 867 (1976); Note, Developments in the Law-Scction 1983 and Federalism, 90 Harv. L. Rev. 1133, 1335 (1977). But see Currie, supra note 24, at 329-30 (criticizing Mitchum).

56. 28 U.S.C. $\$ 2283$ (1976). The statute provides:

A court of the United States may not grant an injunction to stay proceedings in a State court except as expressly authorized by Act of Congress, or where necessary in aid of its jurisdiction, or to protect or effectuate its judgments.

57. The "expressly authorized by Act of Congress" exception is generally construed very narrowly. See Atlantic Coast Line R.R. v. Brotherhood of Locoinotive Eng'rs, 398 U.S. 281, 287 (1970) (exceptions should not be enlarged by loose statutory construction).

58. 407 U.S. at 234 
uniquely federal remedy against incursions under the claimed authority of state law upon rights secured by the Constitution and laws of the Nation."59 To give effect to this plainly stated congressional purpose, the Court accordingly recognized section 1983 as an exception to the Anti-Injunction Act's prohibition. ${ }^{60}$

The Forty-second Congress was concerned that state tribunals either could not or would not adequately protect federally created rights. This congressional distrust led to the creation of the section $1983 \mathrm{rem}-$ edy. ${ }^{61}$ Section 1983 provides an alternative federal remedy for the redress of constitutional violations perpetrated under color of state law. ${ }^{62}$

59. Id. at 239 .

60. Id. at 243. Professor Currie argues that the rationale of Mitchum v. Foster does not indicate that there should be a res judicata or collateral estoppel exception to the full faith and credit statute, 28 U.S.C. $\$ 1738$ (1976). Currie, supra note 24, at 329-30. He points out that the AntiInjunction Act, 28 U.S.C. $\$ 2283$ (1976), contains an express provision for situations in which the Act does not apply. $I d$. He notes that section 1738 contains no such provision and concludes that the plain language of that section forbids exceptions to the application of res judicata or collateral estoppel. Id. Professor Currie fails to consider, however, that the doctrine of collateral estoppel simply carries out a policy favoring finality of judgments. The doctrine is not a hard and fast rule of substantive law. Section 1738 requires federal courts to apply the res judicata and collateral estoppel principles of the state in which the initial judginent was rendered, but soine federal courts, notably the Second Circuit, have concluded that even though a judgment may have been given res judicata or collateral estoppel effect in the state court, coinpeting federal policies may require that the judginent be given lesser effect. See note 28 supra. The "federal courts are not always bound by such prior state decisions." Kremer v. Chemical Constr. Corp., 464 F. Supp. 468, 472 (S.D.N.Y. 1978) (citing Mitchell v. NBC, 553 F.2d 265, 274 (2d Cir. 1977)). See also McCune v. Frank, 521 F.2d 1152, 1156 n.10 (2d Cir. 1975).

Notwithstanding the language of section 1738, this analysis is consistent with the notion that res judicata or collateral estoppel principles are applied in the first instance only after balancing the policy considerations involved. The federal courts thus should be free to consider countervailing federal policies when deciding wliether to prevent the relitigation. The policy of providing a federal foruin for the vindication of constitutional rights under section 1983 is sucli a policy.

The Supreme Court has noted elsewhere that with the enactment of the civil rights statutes after the Civil War, the lower federal courts "became the primary and powerful reliances for vindicating every right given by the Constitution, the laws, and treaties of the Uinited States." Steffel v. Thoinpson, 415 U.S. 452, 464 (1974) (quoting F. Frankfurter \& J. Landis, The BusiNESS OF THE SuPReme COURT 65 (1928) (empliasis added by the Court)). The Court lield in Steffel that Younger v. Harris, 401 U.S. 37 (1971), does not require a federal court to stay proceedings when there is only the threat of a state criminal prosecution but no pending state criminal proceeding as of the date that the federal complaint is filed. 415 U.S. at 475 . See also Huffinan v. Pursue, Ltd., 420 U.S. 592, 617 (1975) (Brennan, J., dissenting) (quoting Steffel, 415 U.S. at 464).

61. Rimmer v. Fayetteville Police Dep't, 567 F.2d 273, 275 (4th Cir. 1977) (citing Mitchum v. Foster, 407 U.S. 225, 242 (1972)). The inembers of the Forty-second Congress were velieinent in their suspicion of the quahty and inotives of state tribunals. See, e.g., Cong. Globe, 42d Cong., 1st Sess. 374-76 (1871) (reinarks of Rep. Lowe) ("[The] records of the [state] tribunals are searched in vain for effective redress [of federally secured rights]. . . . What less than this [the Civil Rights Act of 1871] will afford an adequate remedy?"), quoted in Mitchum v. Foster, 407 U.S. 225, 240 (1972).

62. Justice Douglas described the fears of the Reconstruction Congress in Monroe v. Pape, 365 U.S. 167, 180 (1961): 
Moreover, Congress perceived that in authorizing the federal courts to provide this reinedy, it was permanently altering the relationship between the states and the federal government. ${ }^{63}$

As noted previously, ${ }^{64}$ collateral estoppel is a rule of policy and its application nay be superseded by superior competing policies. One federal judge has stated that "[s]uch a rule of public policy 1nust be watclied in its application lest a blind adherence to it tend to defeat the even firmer established policy of giving every litigant a full and fair day in court." ${ }^{65}$ Decisions since Mitchum ${ }^{66}$ that have questioned the propriety of applying collateral estoppel in section 1983 cases have relied heavily on the legislative purpose behind section 1983-to provide a federal forum for this uniquely federal remedy. ${ }^{67} \mathrm{~A}$ blind adherence to notions of collateral estoppel with respect to section 1983 claims based on fourtl amendinent violations will defeat this policy. 68

\footnotetext{
It is abundantly clear that one reason the legislation was passed was to afford a federal right in federal courts because, by reason of prejudice, passion, neglect, intolcrance or otherwise, state laws might not be enforced and the claims of citizens to the enjoyment of rights, privileges, and immumities guaranteed by the Fourtccnth Amendment might be denied by the state agencies.

63. Mitchum v. Foster, 407 U.S. 225, 242 (1972). See Averitt, supra note 55, at 208; Theis, supra note 55 , at 867 .

64. See note 60 supra and text accompanying note 20 supra.

65. United States v. Silliman, 167 F.2d 607, 614 (3d Cir. 1948) (action for fraud). See Fernandez v. Trias Monge, 586 F.2d 848, 856 n.11 (1st Cir. 1978) ("modern analysis has tended away from the technicalities in favor of the purposes of issue and claim preclusion"). Cf. Currie, supra note 24, at 341 ("IT)he desired result could be reached by redefining 'cause of action' to reflect modern notions of the underlying policies" of res judicata).
}

66. Mitchum v. Foster, 407 U.S. 225 (1972).

67. See, e.g., Preiser v. Rodriguez, 4 II U.S. 475, 509 n.14 (1973) (Brennan, J., dissenting):

The Court correctly notes that a number of lower courts have assuncd that the doctrine of res judicata is fully applicable to cases brought under $\$ 1983$. But in view of the purposes underlying enactment of the [Civil Rights] Act-in particular, the congrcssional misgivings about the abihty and inclination of state courts to enforce federally protected rights . . .that conclusion may well be in error.

See also Johnson v. Mateer, 625 F.2d 240 (9th Cir. 1980); McCurry v. Allen, 606 F.2d 795, 799 (8th Cir. 1979) (special role of federal courts in protecting civil rights), cert. granted, $100 \mathrm{~S}$. Ct. 1012 (1980) (No. 79-935); Ornstem v. Regan, 574 F.2d 115, 117 (2d Cir. 1978) (the court declines to apply the broader doctrine of res judicata, but does apply collateral estoppel, on the ground that section 1983 is supplementary to state remedies); Rimmer v. Fayetteville Police Dep't, 567 F.2d 273, 275 (4th Cir. 1977) (Congress is distrustful of state courts); Lombard v. Board of Educ., 502 F.2d 631, 635 (2d Cir. 1974) (the federal remedy is supplementary to the state remedy-to apply res judicata overrules the essence of Monroe v. Pape, 365 U.S. 167 (1961)), cert. denied, 420 U.S. 976 (1975); Clark v. Lutcher, 436 F. Supp. 1266, 1272 (M.D. Pa. 1977) (clear policy of affording litigants a federal forum); Moran v. Mitchell, 354 F. Supp. 86, 88 (E.D. Va. 1973) (there is a strong interest in providing a federal forum).

68. Nonetheless, an exception to the usual collateral estoppel principles is warranted only im cases in which a litigant was compelled to litigate his federal constitutional claim in a state criminal prosecution. If the litigant has a choice of forum and chose the state tribunal, there is no valid reason to permit him to bring the same claim in federal court under an exception to collateral estoppel premised in the importance of affording a federal forum to hear a litigant's claim. See Parker v. McKeithen, 488 F.2d 553 (5th Cir.), cert. denied, 419 U.S. 838 (1974). In Parker the 


\section{B. The Inadequacy of the State Forum.}

Congress enacted section 1983 as part of the Civil Rights Act of 1871 during an unusual period of the nation's history; radical measures were required to reunite the republic divided in the Civil War. Conditions changed significantly in the century between the enactment of section 1983 and the decision in McCurry. Although the Forty-second Congress's tremendous distrust of state courts is no longer warranted, ${ }^{69}$ the conclusion that state tribunals are as competent as federal courts to adjudicate constitutional claims may also be unwarranted. Institutional differences between the state and federal judicial systems ${ }^{70}$ weigh heavily in favor of the continued availability of a federal forun for fourth amendinent claims filed pursuant to section 1983.

The sovereignty of states within their own spheres of interest may proinote a provincialisin that is not appropriate when federal constitu-

plaintiff had voluntarily sought relief in state court and had received an adverse final judgment. The Court of Appeals for the Fifth Circuit held that he was collaterally estopped from bringing a section 1983 action in federal court in order to relitigate issues previously deternimed in the state action. See also Brown v. Chastain, 416 F.2d 1012, 1014 (5th Cir. 1969) (federal courts will not provide a forum in which disgruntled parties can relitigate federal claims), cert. denied, 397 U.S. 951 (1970). But of. Tomanio v. Board of Regents, 603 F.2d 255, 258 (2d Cir.) (a constitutional claim not raised in a prior state proceeding is not barred in federal court by res judicata), rev'd on other grounds, $100 \mathrm{~S}$. Ct. 1790 (1980).

On the other hand, when federal jurisdiction is properly invoked, the litigant's choice of a federal forum should be respected. See Zwickler v. Koota, 389 U.S. 241, 248 (1967) (it is the duty of a federal court to respect a litigant's choice of a federal foruin); England v. Louisiana State Bd. of Medical Examiners, 375 U.S. 41 1, 415 (1964) (fundamental objections to forcing a litigant who has properly invoked federal court jurisdiction to accept a state court judgment).

69. One federal judge has noted that "[i]t would be presumptuous to claim that federal judges are unore competent, conscientious, or learned than their state brethren in the area of federal rights." Lay, Modern Administrative Proposals for Federal Habeas Corpus: The Rights of Prisoners Preserved, 21 DE Paul L. Rev. 701, 716 (1972).

In Turco v. Monroe County Bar Ass'n, 554 F.2d 515 (2d Cir.), cert. denied, 434 U.S. 834 (1977), the court reached a similar conclusion, stating: "Turco, as appellees did in Huffman $v$. Pursue, Ltd. [420 U.S. 592 (1975)] . . ., is 'urging [the Court] to base a rule on the assuinption that state judges will not be faithful to their constitutional responsibilities.' And like the Supreme Court, "[t]his we refuse to do." " 554 F.2d at 520 (quoting 420 U.S. at 611). See also Deane Hill Country Club, Inc. v. City of Knoxville, 379 F.2d 321, 325 (6th Cir. 1967) ("State courts are competent to decide questions arising under the federal constitution"); Aldisert, Judicial Expansion of Federal Jurisdiction: A Federal Judge's Thoughts on Section 1983, Comity and the Federal Caseload, 1973 LAw \& Soc. ORDER 557.

One commentator, noting the uniforn patteru that the Burger Court has followed in limiting access to the federal courts, has suggested that the state courts assume the task of protecting federally secured rights. See Comment, Protecting Fundamental Rights in State Courts: Fitting a State Peg into a Federal Hole, 12 HARv. C.R.-C.L.L. REv. 63, 87 (1977). This solution is somewhat shortsighted, however. The problem of protecting federal constitutional rights is not solved by forcing the state courts to fill the gap left by the Burger Court's reduction of federal judicial power, but by inaintaining and strengthening section 1983 as a viable remedy.

70. For a good discussion of such differences see Neuborne, The Myth of Parity, 90 HARV. L. REV. 1105 (1977). 
tional claims are being adjudicated. ${ }^{71}$ Although federal courts sometimes determme questions of state law, and state courts occasionally determme questions of federal law, each judicial system is most competent $\mathrm{m}$ its own field. In the Federalist Papers, Alexander Hamilton observed that

the most discerning cannot foresee how far the prevalency of a local spirit may be found to disqualify the local tribunals for the jurisdiction of national causes . . . . State judges, holding their offices during pleasure from year to year, will be too little independent to be relied on for an inflexible execution of the national laws. ${ }^{72}$

Justice Brennan, who has served on both the New Jersey and the United States Supreme Courts, has stated that "[m]y state court responsibility, while it mcluded jurisdiction over federal questions and federal-state conflicts, was inevitably colored by the fact that I was, after all, a state judge. My federal court responsibility, on the other hand, demands a national perspective . . . ."73

A member of the state judiciary, regardless of his mdividual talents, ${ }^{74}$ is, as Brennan imphes, likely to be more influenced by local concerns than is a federal judge. State trial judges may lack the necessary national perspective for adequate resolution of problems of constitutional dimension. Members of the state bench at the crimimal, domestic relations, and civil court levels are "steadily confronted by distasteful and troubling fact patterns which can sorely test abstract constitutional doctrine and foster a jaded attitude toward constitutional rights." 75 An obvious example arises im the fourth amendment context. A state judge may be faced with a choice between sanctioning a fourth amendment violation and applying the exclusionary rule. Application of the exclusionary rule often permits an otherwise guilty and dangerous felon to go free. A state judge who beheves that enforcement of fourth amendment rights through the exclusionary rule is socially harmful and un-

71. But see Stone v. Powell, 428 U.S. 465, $493-94$ n.35 (1976):

Despite differences in institutional environinent and the unsympathetic attitude to federal constitutional claims of some state judges $m$ years past, we are unwilling to assuine that there now exists a general lack of appropriate sensitivity to constitutional rights in the trial and appellate courts of the several States.

72. The Federalist No. 81 (A. Hamilton). See McCormack, Federalism and Section 1983. Limitations on Judicial Enforccment of Constitutional Claims, Part IJ, 60 VA. L. REv. 250, 262-63 (1974).

73. Brennan, Some Aspects of Federalism, 39 N.Y.U. L. REv. 945, 948 (1964).

74. Professor Neuborne contends that the average federal judge is technically more competent to adjudicate constitutional issues than is the average state judge. Neuborne, supra note 70 , at 1121-24.

75. Id. 1125 . 
just may be less eager to vindicate constitutional principles than his federal counterpart. ${ }^{76}$

Furthermore, state courts are not part of a unified judicial system, as are the federal courts. A state court decision on federal constitutional issues therefore has minimal precedential value. The unified federal judiciary is better equipped to provide a uniform and high standard of protection to rights guaranteed by the Constitution. ${ }^{77}$ Moreover, the Supreme Court can review state court judgments in only a small percentage of cases-an inadequate means of assuring that constitutional principles are consistently and uniformly apphed. ${ }^{78}$

\section{Adverse Effects of Collateral Estoppel on State Court Defendants.}

The apphication of collateral estoppel against a section 1983 plaintiff who has unsuccessfully litigated his fourth amendment claims in a prior state suppression hearing does more than merely deny him access to a federal forum. The threat of collateral estoppel adversely affects the state criminal defendant even before he sets foot in the courtroom, because he must choose between two dangerous and unattractive alternatives. He may forego his constitutional defenses in the state proceeding in order to preserve them for a subsequent section 1983 action. In this case, the defendant increases the risk of a criminal conviction. Alternatively, the defendant may raise all potential constitutional issues at his state trial. This option has two distinct disadvantages. First, if he is convicted in the state trial, the defendant loses the federal forum that section 1983 supposedly secures for him. Second, by raising constitutional defenses the defendant inay complicate his state trial and impair his efforts to mount an effective defense strategy on the merits of his case. ${ }^{79}$ The state criminal defendant is thus faced with the prospect of an adverse criminal judgment on the one hand, or the denial of his

76. See McCormack, supra note 72, at 262-64; Note, supra note 55, at 1340.

77. See Basista v. Weir, 340 F.2d 74, 86 (3d Cir. 1965). The court stated: "We believe that the benefits of the [Civil Rights] Acts were intended to be uniform throughout the United States, that the protection to the individual to be afforded by them was not intended by Congress to differ from state to state ...."

78. Comment, supra note 69 , at 87.

79. In Stone v. Powell, 428 U.S. 465 (1976), the Court indicated that the application of the exclusionary rule detracts from the litigation of the substantive issues: "[T]he focus of the trial, and the attention of the participants therein, are diverted from the ultimate question of guilt or innocence that should be the central concern in a criminal proceeding." $I d$. at 489-90.

Federal Rule of Criminal Procedure 12(b)(3) makes it likely that the parties will place great emphasis on the fourth amendment issue. That rule requires a defendant to file a motion to suppress evidence in advance of trial, thus avoiding interruption of the trial's orderly progress. See Segurola v. United States, 275 U.S. 106, 111-12 (1927). Because the accused will often be acquitted if the relevant evidence is excluded, both parties will view a victory on the fourth amendment issue as critically important. 
federal forum on the other. One federal court has noted that the defendant caught in this dilemma is faced with hittle choice at all. ${ }^{80}$

\section{Summary.}

Even if state courts are adequately equipped to adjudicate federal constitutional claims, it cannot be concluded that a federal forum is no longer necessary or desirable for the adjudication of section 1983 actions. A basic premise of section 1983 is that the plaintiff who alleges a denial of federally secured rights by state instrumentalities has a right to have his clainn adjudicated in a federal forum. ${ }^{81}$ Congress has not changed its policy of providing a federal forum for section 1983 actions simply because state judicial systems have improved their capacity and willingness to litigate federal constitutional claims. Indeed, the proposed Civil Rights Inprovement Act of 1979 provides: "In evaluating the need for relief under this Act, no court of the United States shall consider the availability of a remedy under the laws, ordinances, or regulations of any State, territory, subdivision thereof, or the District of Coluinbia." 82 Moreover, this proposed legislation expressly provides that merger and bar should apply to section 1983 actions only when the plaimtiff voluntarily instituted the prior action. ${ }^{83}$ Thus, nonapplication of collateral estoppel to a section 1983 action that follows a state criminal proceeding in whicli the section 1983 plaintiff was an mvoluntary party complies with this provision. Should the Civil Rights Improvement Act of 1979 be enacted, this clearly expressed congressional policy regarding the scope of the section 1983 remedy would override the judicially inposed bar of collateral estoppel. This legislation evidences an intent by at least some members of the Congress to preserve section 1983 as a federal reinedy available in a federal forum.

Justice Brennan has eloquently stated the relevant policy favoring the availability of a federal forum:

Adopting the premise that state courts can be trusted to safeguard individual rights, the Supreme Court has gone on to limit the protective role of the federal judiciary. But in so doing, it has forgotten that one of the strengths of our federal system is that it provides a

80. Moran v. Mitchell, 354 F. Supp. 86, 88 (E.D. Va. 1973) ("If traditional concepts of collateral estoppel apply, then, a state defendant is faced with a Hobson's choice"). See Note, supra note 55 , at 1340 .

81. See Zwickler v. Koota, 389 U.S. 241, 248 (1967) (it is the duty of a federal court to respect a litigant's choice of a federal forum); England v. Louisiana State Bd. of Medical Examiners, 375 U.S. 411 , 415 (1964) (fundamental objection to forcing a hitigant to accept a state court judgment when the jurisdiction of a federal court is properly invoked).

82. S. 1983, 96 th Cong., 2 d Sess. $\$ 4$ (1979).

83. Id. $\S 2(f)(3)$. 
double source of protection for the rights of our citizens. Federalism is not served when the federal half of that protection is crippled. ${ }^{84}$ The availability of a federal forum for section 1983 actions thus remains a vital policy objective. The doctrine of collateral estoppel sliould not apply where it would defeat the strong policy of providing a federal forum for section 1983 actions.

In a related context, the federal courts have declined to apply res judicata or collateral estoppel when there is a strong imdication of congressional intent to provide a federal forum for certain causes of action. Specifically, the federal courts will not bar relitigation of the cause of action on the ground of res judicata or collateral estoppel when Congress has granted exclusive jurisdiction to the federal courts in certain antitrust litigation.85 If res judicata or collateral estoppel would threaten the effective enforcement of the antitrust laws by denying access to the federal system, the courts refuse to apply the doctrines. Ainple precedent thus exists for an exception to the operation of collateral estoppel when fourth amendment claims are bemg heard pursuant to section 1983. Certainly, the need for enforcement of fourth ainendment rights is at least as compelling as the need for enforceinent of antitrust prolibitions. ${ }^{86}$

\section{Considerations of Comity}

The principle that underlies the doctrine of coinity is that the courts of one sovereign should give effect to the laws and judicial decisions of another sovereign, out of deference and inutual respect rather than out of a sense of obligation. The Supreme Court has noted that comity reflects

a proper respect for state functions, a recognition of the fact that the entire country is made up of a Union of separate state governments, and a continuance of the belief that the National Government will fare best if the States and their institutions are left free to perform their separate functions in their separate ways. ${ }^{87}$

84. Brennan, State Constitutions and the Protection of Individual Rights, 90 HARv. L. Rev. 489, 502-03 (1977).

85. Lyons v. Westinghouse Elec. Corp., 222 F.2d 184 (2d Cir.) (no res judicata when a federal plaintiff was a state court defendant), cert. denied, 350 U.S. 825 (1955); see Note, supra note 28. See also Kremer v. Cheınical Constr. Corp., 464 F. Supp. 468, 472 (S.D.N.Y. 1978) (res judicata not applied to title VII action).

86. Although the federal courts do not have exclusive jurisdiction over section 1983 actions, the congressional policy of providing a federal remedy for the denial of constitutional rights by state authorities is certainly strong enough to support an analogous exception to the operation of collateral estoppel. One commentator has noted that the framers of section 1983 probably considered the concurrent jurisdiction of state courts in section 1983 actions to be of little practical importance. See Theis, supra note 55, at 868.

87. Juidice v. Vail, 430 U.S. 327, 334 (1977) (quoting Huffman v. Pursue, Ltd., 420 U.S. 592 , 601 (1975) (quoting Younger v. Harris, 401 U.S. 37, 44 (1971))). 
The doctrine of collateral estoppel promotes comity by prohibiting litigation in federal court of issues that were previously adjudicated in a state court. ${ }^{88}$ When a section 1983 damage action follows a state criminal conviction, however, the concerns that the concept of comity addresses are not seriously implicated.

\section{A. Comity Considerations in McCurry v. Allen. ${ }^{89}$}

Although the $M c$ Curry court held that the plaintiff was not collaterally estopped by the determination at the state suppression hearing, it nevertheless ordered the district court to abstain from adjudicating McCurry's scction 1983 claim until completion of the state appellate process. ${ }^{90}$ The court based its decision to abstain on a line of cases beginning with Younger v. Harris.91 In Younger the Supreme Court held that a federal court inay not enjoin a pending state criminal prosecution except in certain exceptional circumstances. ${ }^{92}$ The Court stated that the underlying reason for restraining federal courts from enjoining pending state criminal prosecutions is the notion of comity-the need to respect the exercise of state functions..$^{93}$ Deference is to be accorded to the state criminal process unless extraordmary circumstances render the state court incapable of fully and fairly adjudicating the federal issues before it. ${ }^{94}$

The Burger Court has steadily and consistently expanded the Younger rule. The Court first extended Younger to a state civil nuisance action, on the theory that such an action is analogous to the enforceinent of a criminal prohibition..$^{95}$ Next, the Court applied the Younger abstention doctrine to state civil contempt proceedings; ${ }^{96}$ later, the Court forbade federal courts to enjoin the operation of a state attachment statute. ${ }^{97}$ Finally, in Moore v. Sims, ${ }^{98}$ the Court announced

88. Vestal, Res Judicata/Preclusion by Judgment: The Law Applied in Federal Courts, 66 MiCH. L. Rev. 1723, 1739 (1968); Comment, supra note 19, at 96.

89. 606 F.2d 795 (8th Cir. 1979), cert. granted, 100 S. Ct. 1012 (1980) (No. 79-935).

90. 606 F.2d at 799.

91. 401 U.S. 37 (1971).

92. Id. Federal injunctive intervention in a pending state proceeding may be permissible if irreparable injury is "both great and immediate," id. at 46 (quoting Fenner v. Boykin, 271 U.S. 240, 243 (1926)); if the state statute is "flagrantly and patently violative of express constitutional prohibitions," 401 U.S. at 53 (quoting Watson v. Buck, 313 U.S. 387, 402 (1941)); or if there is proof of bad faith, harassment, or "any other unusual circumstances that would call for equitable relief," 401 U.S. at 54.

93. 401 U.S. at 44.

94. Kugler v. Helfant, 421 U.S. 117, 124 (1975) (reversing a federal court injunction staying a pending state criminal proceeding).

95. Huffinan v. Pursue, Ltd., 420 U.S. 592, 604 (1975).

96. Juidice v. Vail, 430 U.S. 327 (1977).

97. Trainor v. Hernandez, 431 U.S. 434 (1977).

98. 442 U.S. 415 (1979). The Burger Court consistently has limited the power of the federal judiciary to intrude upon the affairs of the states. See Cox, Federalism and Individual Rights Under 
a broad extension of the Younger doctrine to civil proceedings involving important state interests.

The Supreme Court has not held that the Younger abstention doctrine applies to damage actions. ${ }^{99}$ Currently, the doctrine is limited to the prohibition of federal injunctions that stay pending state civil or criminal proceedimgs. ${ }^{100}$ In $M c$ Curry, however, the Court of Appeals for the Eighth Circuit believed it "appropriate to temporarily abstain until the Missouri courts have had the opportunity to directly review appellant's conviction and the underlying search of his home." 101 In

the Burger Court, 73 Nw. U.L. REv. 1, 2 (1978); Michael, The "New" Federalism and the Burger Court's Deference to the States in Federal Habeas Proceedings, 64 Iowa L. Rev. 233 (1979). The majority of the Court has apparently perceived that the potential displacement of the state courts by the federal courts poses a threat to the federal system. Moore v. Sims, 442 U.S. at 423.

This trend toward extensive limitations on the power of the federal judiciary is a radical departure from the philosophy of the Warren Court and the principles enunciated in Mitchum v. Foster, 407 U.S. 225 (1972). In Mitchum the Court reaffirmed the federal courts' role as the primary guardians of federal constitutional rights. The change in attitude of the Burger Court is illustrated by the Younger abstention doctrine. The Court has stated that the policy of forbidding federal injunctive relief against state criminal prosecutions is "founded on the premise that ordinarily a pending state prosecution provides the accused a fair and sufficient opportunity for vindication of federal constitutional rights." Kugler v. Helfant, 421 U.S. 117, 124 (1975) (reversing a federal court injunction staying a pending state criminal proceeding). See generally Morrison, Rights Without Remedies: The Burger Court Takes the Federal Courts Out of the Business of Protecting Federal Rights, 30 RuTGERs L. REv. 841, 841-42 (1977); Zeigler, An Accommodation of the Younger Doctrine and the Duty of the Federal Courts 10 Enforce Constitutional Safeguards in the State Criminal Process, 125 U. PA. L. REV. 266 (1976); Comment, supra note 69, at 63-66.

99. See Juidice v. Vail, 430 U.S. 327,339 n.16 (1977). The Court limited its holding, stating: "The issue of damages is therefore not before us, and we intimate no opinion as to the applicability of Younger-Huffiman principles to a $\S 1983$ suit seeking only such relief in the District Court." Id. See Zurek v. Woodbury, 446 F. Supp. 1149, 1152 (N.D. Ill. 1978).

100. Moore v. Sims, 442 U.S. 415 (I979).

101. 606 F.2d at 799. After persuasively arguing that the operation of collateral estoppel threatens the effectiveness of the federal remedy provided by section 1983, the court denied the appellant access to that remedy by requiring the district court to abstain until the state appellate process had been completed.

Apparently, the McCurry panel believed that considerations of comity could best be served by requiring the plaintiff to exhaust state remedies before seeking section 1983 relief. Exhaustion is required in the related context of federal habeas corpus. See 28 U.S.C. $\$ 2254$ (b) (1976). Exhaustion is not a jurisdictional prerequisite but is founded on the more flexible principles of comity. Doescher v. Estelle, 454 F. Supp. 943, 946 (N.D. Tex. 1978) (citing Ballard v. Maggio, 544 F.2d 1247 (5th Cir. 1977)). The requirement that one exhaust state remedies before invoking the federal habeas remedy gives the state judicial system an opportunity to correct its own error. Wilwording v. Swenson, 404 U.S. 249, 250 (1971); Fay v. Noia, 372 U.S. 39I, 438 (1963).

State judicial remedies need not be exhausted in section 1983 actions; the section 1983 remedy supplements the state remedy. Monroe v. Pape, 365 U.S. 167 (1961), rev'd in part on other grounds, Monell v. Department of Social Servs., 436 U.S. 658 (1978). "[T] he state remedy need not be first sought and refused before the federal one is invoked." 365 U.S. at 183. The McCurry court's requirement that state remedies be exhausted prior to the institution of a section 1983 action in federal court is therefore inappropriate. Furthermore, federal abstention until the state 
ordering the district court to abstain from hearing the appellant's section 1983 damage action, the court of appeals went further than was necessary or warranted. The principles of comity that underlie the Younger doctrine are not implicated when a federal court, in a section 1983 dainage action, adjudicates issues that were previously determined im a state proceeding from which an appeal is pending.

\section{B. Collateral Estoppel and the Comity Doctrine.}

The evil sought to be remedied in Younger was the direct interference with ongoing state judicial proceedings. ${ }^{102}$ An imjunction that stays a pending proceeding greatly interferes with the enforcement of substantive state policies. A section 1983 damage action that re-exammes issues of fact and law raised in the prior proceeding, however, does not interfere witli the implementation of such policies. ${ }^{103} \mathrm{~A}$ damage action filed pursuant to section 1983, as in McCurry, does not impinge on tlie deterınination of guilt or innocence made $m$ the state criminal trial. The issue of the constitutionahty of a search and seizure does not go to the merits of the conviction or acquittal. Moreover, a determination in a section 1983 action that a search and seizure violated the fourtl amendinent would not necessarily require the exclusionary rule to be imvoked retroactively. Although the exclusionary rule is currently utilized to enforce the fourth amendment, the Supreme Court has intimated that it is not a constitutionally required device for enforcing fourtl annendment rights. ${ }^{104}$ The Court has heavily criticized the exclusionary rule and has indicated that if a viable alternative remedy for fourth amendment violations were available, the exclusionary rule would be promptly discarded. ${ }^{105}$ Federal determmation of fourth ainendment violations pursuant to a section 1983 damage action should

appellate court renders a decision may threaten the integrity and dignity of the state court more than if the district court hears the case before the state appellate process is completed. Thus, there is no valid reason for the federal court to abstain on the basis of comity considerations.

102. Younger v. Harris, 401 U.S. 37, 43-46 (1971). The Court, quoting Fenner v. Boykin, 271 U.S. 240, 243-44 (1926), stated that "[o]rdinarily, there should be no interference with such [state] officers; primarily, they are charged with the duty of prosecuting offenders against the laws of the State and must decide when and how this is to be done." 401 U.S. at 45. See generally Aldisert, On Being Civil to Younger, Il ConN. L. Rev. 181 (1979).

103. One district court has held that

[a]lthough federalism is an important restramt on the exercise of discretionary jurisdiction by the federal courts, in hight of the mimimal interference with the state criminal proceedimg, the clear policy of affording litigants a federal forum in which to vindicate constitutional rights represented by 42 U.S.C. $\$ 1983 \ldots$ and the doubts which this Court entertains with respect to its power to decline to exercise its jurisdiction, the Court will deny Defendants' motion to dismiss this action on the basis of connity.

Clark v. Lutcher, 436 F. Supp. 1266, 1272 (M.D. Pa. 1977).

104. See Stone v. Powell, 428 U.S. 465 (1976).

105. Id. at 500-01 (Burger, C.J., concurring). 
therefore not automatically trigger the exclusionary rule. A section 1983 damage award after a state criminal conviction would not impugn the validity or integrity of the state court conviction, or demean the state's important interest in enforcing its criminal law. The conviction would remain valid, but section 1983 would afford the defendant an opportunity to vindicate his fourth ainendment rights. Thus, the policies that underlie the doctrine of comity are not subverted by the recognition of an exception to collateral estoppel that permits section 1983 damage actions following state criminal prosecutions.

The possibility that a federal court may reach a result different from that reaclied by the state court on the fourth ainendment issue does not impinge upon considerations of comity or federalism. Such conflicting results are a necessary consequence of our federal system. The Supreme Court acknowledged this principle in Doran v. Salem Inn, Inc. ${ }^{106}$ In Doran three business establishments brought a section 1983 action to enjoin the enforcement of an ordinance proscribing topless dancing. The plaintiffs alleged that the ordinance violated the plaintiffs' first and fourteenth ainendinent rights, but only one of the three corporations had actually violated the criminal ordinance. Because a state criminal prosecution was pending against this corporation, Younger abstention would normally have prevented a federal court from granting mjunctive relief. The Younger rule did not, however, operate against the two businesses that had not violated the ordinance. The Court of Appeals for the Second Circuit had held that this distinction was unwarranted $\mathrm{m}$ view of the interests of avoiding contradictory outcomes, conserving judicial energy, and maintaining a consistent method for determining when federal courts should defer to state prosecutions. ${ }^{107}$ The United States Supreme Court reversed, holding that "the interest of avoiding conflicting outcomes in the litigation of similar issues, while entitled to substantial deference in a umitary system, inust of necessity be subordinated to the claims of federalism in this particular area of the law."108 The state court could therefore find the ordinance constitutional and convict the corporation that had violated the ordinance even though the federal court might grant the other two corporations declaratory or mjunctive relief if it determined in the section 1983 action that the ordinance was unconstitutional.

Similarly, collateral estoppel need not be used to prevent federal and state courts from reaching inconsistent results (although inconsis-

106. 422 U.S. 922 (1975).

107. Salem Inn, Inc. v. Frank, 501 F.2d 18, 22 (2d Cir. 1974), rev'd sub nom. Doran v. Salem Inn, Inc., 422 U.S. 922 (1975).

108. 422 U.S. at 928. 
tencies are obviously undesirable) in cases arising out of the same facts. Federalism does not demand that results be consistent when two independent judicial systeins are involved. Moreover, federalism protects federal interests as well as state interests. If state interests were at all times supreme, the concept of a federal union would become meaningless.

\section{Independent Constitutional Inquiry in Federal Prosecutions.}

A person charged with a violation of state law may be subject to a state criminal prosecution and a federal prosecution based on the same facts. The defendant may, in the state criminal prosecution, be successful in his motion to suppress evidence upon allegations that the police searched for and seized evidence in violation of his fourth amendment rights. In this case the defendant is likely to wim a judgment of acquittal, for the prosecution often cannot prove the elements of the offense without the seized evidence. If a federal grand jury subsequently indicts the defendant for federal offenses that arise out of the same facts litigated in the state proceeding, ${ }^{109}$ he may again move to suppress the evidence. Considerations of comity might seein to require that the federal court accept the finding of the state court. It is well settled, however, that the federal judge must conduct an independent inquiry to determine whether the state police officers violated the fourth amendment. ${ }^{110}$ Comity and federalism do not compel the federal judge to accept the finding of the state court on the fourth amendment issue because independent inquiry into the same facts and issues of law does not seriously interfere with the operation of the state crimmal justice system. Moreover, the important interest in enforcing the federal crim-

109. A federal prosecution arising out of the same facts which resulted in an earlier state court conviction does not violate principles of double jeopardy. An act "denounced as a crine by both national and state sovereignties is an offense against the peace and dignity of both and inay be punished by each. . . . The defendants thus committed two different offenses by the same act . . . United States v. Lanza, 260 U.S. 377, 382 (1922); accord, Bartkus v. Illinois, 359 U.S. 121, 129 (1959).

110. Elkins v. United States, 364 U.S. 206, 223-24 (1960). The Court stated:

In determining whether there has been an unreasonable search and seizure by state officers, a federal court must make an independent inquiry, whether or not there has been such an inquiry by a state court, and irrespective of how any such inquiry may have turned out. The test is one of federal law, neither enlarged by what one state court may have countenanced, nor dimimished by what another inay have colorably suppressed.

Id. In Elkins the Court overruled the "silver platter" doctrine, which had perinitted the federal government to use evidence obtained by state officers in violation of the fourth amendment as Iong as federal agents had not participated in the search. Id. See also Rios v. United States, 364 U.S. 253 (1960); United States v. Garrett, 565 F.2d 1065 (9th Cir. 1977), cert. denied, 435 U.S. 974 (1978); United States v. Bedford, 519 F.2d 650, 654 (3d Cir. 1975); Boyle v. United States, 395 F.2d 413, 4 I5 (9th Cir.), cert. denied, 393 U.S. 1089 (1968); United States v. Beigel, 370 F.2d 751, 756 (2d Cir.), cert. denied, 387 U.S. 930 (1967); Vuin v. Burton, 327 F.2d 967 (6th Cir. 1964). 
inal law requires the federal court to readjudicate fourth amendment questions.

This rule implies that a federal court should also make an imdependent inquiry in a section 1983 suit for damages that follows a state criminal proceeding. ${ }^{111}$ Many of the same conditions are present in both situations. First, the vindication of an important federal interest is at stake-the provision of a federal forum to adjudicate allegations that the state has deprived an individual of constitutional rights. Second, a section 1983 damage action will neither interfere with substantive state pohicies nor.impugn the integrity of the prior state judginent. Although collateral estoppel is often invoked to promote comity and federalisin, a section 1983 damage action for fourth amendment violations that follows a state prosecution does not seriously implicate those concerns. On balance, the scale certainly tips in favor of providing an exception to the application of collateral estoppel.

\section{The Unavailability of Habeas Corpus: Stone v. Powell}

Habeas corpus is an extraordmary remedy, based upon traditions anchored in the common law and the Constitution, for detentions that are fundainentally illegal. ${ }^{12}$ Habeas rehef has traditionally been available in federal courts to a state prisoner whose constitutional claims have been rejected by the state courts. ${ }^{113}$ The remedy is available, however, only when all avenues of relief under state law have been exhausted. State prisoners are entitled to federal habeas corpus rehef only upon proof that their imprisonment violates fundamental personal liberties that the United States Constitution protects. ${ }^{114}$

The writ of habeas corpus has generally been exempt from strict application of res judicata principles. ${ }^{115}$ The reason for this exemption

111. The analogy is admittedly imperfect. In a federal prosecution subsequent to a state prosecution, there is no possibility that the United States is collaterally estopped from relitigating issues raised in the state suppression hearing. The United States was not a party to the state criminal action, and "it is fundamental that the party against whom collateral estoppel is asserted inust be a party or privy to the initial hitigation." United States v. Smith, 446 F.2d 200, 202 (4th Cir. 1971) (citing Serio v. United States, 203 F.2d 576 (5th Cir. 1953)). See, e.g., Ferina v. United States, 340 F.2d 837 (8th Cir.), cert. denied, 381 U.S. 902 (1965). Nevertheless, the important point remains: the federal court does not accept or defer to the state court's determination because of comity.

112. Townsend v. Sain, 372 U.S. 293, 311 (1963). When a state prisoner's application to a federal court for a writ of habeas corpus alleges facts which, if proved, would entitle him to relief, the federal court can conduct a de novo evidentiary hearing.

113. See Brown v. Allen, 344 U.S. 443 (1953); Hill, The Forfeiture of Constitutional Rights in Criminal Cases, 78 Colum. L. Rev. 1050, 1053-54 (1978).

114. 28 U.S.C. $\$ 2254$ (b) (1976).

115. Brown v. Allen, 344 U.S. 443 (1953). According to the Court, "the state adjudication carries the weight that federal practice gives to the conclusion of a court of last resort of another 
is that habeas corpus is an original civil remedy for the enforcement of the right to personal liberty independent of prior criminal proceedings or appellate review. ${ }^{116}$ This independence promotes the policy that "conventional notions of finality in criminal litigation cannot be perinitted to defeat the inanifest federal policy that federal constitutional rights of personal liberty shall not be denied without the fullest opportunity for plenary judicial review." 117

Federal habeas relief, however, is now rarely available to a state prisoner alleging a violation of his fourth amendment rights. In Stone v. Powell, 118 the United States Supreme Court held:

[W] here the State has provided an opportunity for full and fair litigation of a Fourth Amendment claim, the Constitution does not require that a state prisoner be granted federal habeas corpus relief on the ground that evidence obtamed in an unconstitutional search or seizure was introduced at his trial. 119

Before Stone, if the federal court in a habeas action determined that the state court had adinitted evidence at trial that was obtamed in violation of the fourth ainendment, the prisoner would be released.120 In Stone, however, the Court weighed the deterrent effect of the exclusionary rule against the social costs of extending it to collateral review of fourth amendment claims. ${ }^{121}$ The Court concluded that the social costs of providing liabeas corpus review in the case of alleged fourth amendinent violations were too liigh. 122

The Stone v. Powell decision leaves section 1983 as the only vehicle for federal oversight of violations of fourth amendment rights by state officials. A strict application of collateral estoppel to a section 1983 damage action would therefore effectively bar a fourth amend-

jurisdiction on federal constitutional issues. It is not res judicala." $I d$. at 458 (footnote omitted). See Preiser v. Rodriguez, 411 U.S. 475, 497 (1973); Fay v. Noia, 372 U.S. 391, 423 (1963) (res judicata is not wholly applicable in a habeas proceeding).

116. Fay v. Noia, 372 U.S. at $423-24$.

117. Id. at 424 .

118. 428 U.S. 465 (1976).

119. Id. at 482 .

120. Id. at $480-81$.

121. Id. at 489 .

122. Id. at 493-94. The Court explained:

Resort to habeas corpus, especially for purposes other than to assure that no innocent person suffers an unconstitutional loss of liberty, results in serious intrusions important to our system of government. They include "(i) the inost effective utilization of limited judicial resources, (ii) the necessity of finality in crininal trials, (iii) the minimization of friction between our federal and state systems of justice, and (iv) the maintenance of the constitutional balance upon which the doctrine of federalism is founded."

Id. at 49 I n.31 (quoting Schneckloth v. Bustamonte, 412 U.S. 218, 259 (1973) (Powell, J., concurring)). The Court also noted other significant costs of applying the exclusionary rule, such as the interruption of the truth-finding process and the freeing of guilty defendants if a fourth amendment violation is found. 428 U.S. at 490. 
ment claimant from all avenues of federal relief. In McCurry the court's second ${ }^{123}$ inajor rationale for refusing to preclude the section 1983 claimant was the unavailability of habeas corpus under Stone. In fact, many of the cases applying collateral estoppel to section 1983 claims brought by state prisoners indicate that the availability of federal review via the writ of habeas corpus is a necessary condition precedent to a bar of collateral estoppel. ${ }^{124}$

In Rimmer v. Fayetteville Police Department, ${ }^{125}$ decided after Stone, the Court of Appeals for the Fourth Circuit barred a section 1983 action by a prisoner who alleged that the state court had unconstitutionally admitted certain identification testimony at trial. ${ }^{126}$ Significantly, the court applied collateral estoppel only after noting that the issues raised by the plaintiff could be raised in federal court on a petition for habeas corpus. ${ }^{127}$ The court also expressed serious doubts about the propriety of applying collateral estoppel when federal habeas corpus is, under Stone, unavailable to the prisoner. The court noted that state prisoners complaining of illegal searches and seizures would have no access to the federal courts by way of habeas corpus, and that application of the rule of preclusion in such cases might deny a state prisoner access to a federal forum entirely. ${ }^{128}$ The court concluded that "[s]ince it was the general intention of the Civil Rights Act to provide access to a federal forum for the adjudication of federal constitutional rights, the Civil Rights Act itself may present a bar to foreclosure of the issue in those cases." ${ }^{129}$ The Rimmer court's limitation on the effect of

123. The court's first rationale was the special role that the federal courts play in protecting constitutional rights. 606 F.2d at 799. See text accoinpanying notes 51-68 supra.

124. See, e.g., Rimmer v. Fayetteville Police Dep't, 567 F.2d 273, 276 (4th Cir. 1977) (foreclosure of habeas under Stone raises a problem in applying collateral estoppel); Meadows v. Evans, 550 F.2d 345, 346 (5th Cir. 1977) (Goldberg, J., concurring and dissenting) (the absence of habeas raises troublesome questions). Cases decided before Stone, and assuining habeas rehef was available, include Thistlethwaite v. City of New York, 497 F.2d 339, 343 (2d Cir.) (habeas corpus is generally available), cert. denied, 419 U.S. 1093 (1974); Brazzel v. Adains, 493 F.2d 489 (5th Cir. 1974) (collateral estoppel should be applied because of the availability of habeas corpus); Alexander v. Einerson, 489 F.2d 285 (5th Cir. 1973) (per curiam) (habeas corpus rather than seetion 1983 is the proper remedy for a claim based on the fourth amendinent); Von Lusch v. C \& P Telephone Co., 457 F. Supp. 814, 819 (D. Md. 1978) (the plaintiff was precluded because he could raise the issues on federal habeas corpus); Pyles v. Keane, 418 F. Supp. 269, 274 n.4 (S.D.N.Y. 1976) (collateral estoppel does not bar an attack by habeas corpus); Moran v. Mitchell, 354 F. Supp. 86, 88 (E.D. Va. 1973) (the court doubts the propriety of applying collateral estoppel where habeas corpus is not available).

125. 567 F.2d 273 (4th Cir. 1977).

126. Id.

127. Id. at 277. See Von Lusch v. C \& P Telephone Co., 457 F. Supp. 814, 819 (D. Md. 1978).

128. 567 F.2d at 276.

129. Id. 
collateral estoppel thus emphasizes the importance of preserving some federal forum for the fourth amendment claimant. 130

\section{A. The Social Cost Rationale of Stone.}

The Supreme Court concluded in Stone that ordmarily a state court determination of fourth amendment claims is adequate and should preclude federal habeas corpus relief. ${ }^{131}$ In essence, therefore, Stone holds that the traditional exception of habeas corpus from res judicata or collateral estoppel no longer applies in the fourth amendment context. ${ }^{132}$ Stone might similarly prohibit an exception to the operation of collateral estoppel when a claimant seeks review of a search and seizure pursuant to section 1983. Arguably, if the strong interest in personal liberty does not justify the social costs of providing habeas relief, then the interest im vimdicating fourth amendment rights through a section 1983 damage action does not warrant incurring such social costs. ${ }^{133}$ This conclusion, however, does not necessarily follow from Stone. Stone holds only that enforcement of the exclusionary rule via federal habeas corpus is too costly, not that a violation of the fourth amendment is an inferior or trivial infringement of individual rights. The case stands for the proposition that the exclusionary rule is not always an appropriate remedy for fourth amendment violations. ${ }^{134}$

The Supreme Court's apparent dissatisfaction with the exclusion-

130. Id. Von Lusch v. C \& P Telephone Co., 457 F. Supp. 814,819 (D. Md. 1978).

131. 428 U.S. at $481-82$.

132. Federal habeas corpus relief is unavailable if the fourth amendment claimant has had an "opportunity for full and fair litigation" of his claim in state court. Id.

133. Both commentators and courts liave likened habeas corpus to section 1983. See, e.g., Florida State Bd. of Dentistry v. Mack, 401 U.S. 960 (1971) (White, J., dissentimg from denial of petition for certiorari); Brown v. Chastain, 416 F.2d 1012, 1014 (5tl Cir. 1969) (Rives, J., dissenting); McCormack, supra note 72, at 259; Theis, supra note 55, at 872-73. Both remedies help to vindicate constitutional principles. Significantly, habeas corpus, like section 1983, is generally available regardless of the guilt or innocence of the applicant. But see Stone v. Powell, 428 U.S. $465,492 \mathrm{n} .31$ (1976) (questioning the soundness of habeas corpus when the matter at issue has "no bearing on the basic justice of his incarceration").

There are important differences, lowever. Habeas corpus is an extraordinary remedy that recognizes the paramount importance of personal liberty. Fay v. Noia, 372 U.S. at 423-24. A dainage action under section 1983 essentially sounds in tort and does not lave the urgent purpose of limiting wrongful restraints on personal liberty that liabeas corpus has. See Ellis v. Dyson, 421 U.S. 426, 440 n.6 (1975) (Powell, J., dissenting) ("In my view, the liarm asserted in habeas corpus proceedings-restraint on liberty-may justify a broader scope of collateral attack than would the kinds of injury normally concerned in actions under $\left.\$ 1983^{\prime \prime}\right)$. See also Note, The Preclusive Effect of State Judgments on Subsequent 1983 Actions, 78 Colum. L. Rev. 610, 621 (1978).

134. Some courts have imterpreted Stone as a denial of the habeas remedy to redress any constitutional violations that do not bear on the basic guilt or innocence of the prisoner. See, e.g., Richardson v. Stone, 421 F. Supp. 577, 579 (N.D. Cal. 1976) (applying the Stone "opportunity for full and fair litigation" standard to a fifth amendment claim on petition for habeas corpus). See generally United States ex rel. Sanders v. Rowe, 460 F. Supp. 1128, 1141-44 (N.D. Ill. 1978) 
ary rule ${ }^{135}$ does not mean that an effective federal remedy for such imfringements is either unnecessary or undesirable. Concurring in Stone, Chief Justice Burger reasoned that abolition of the exclusionary rule would force Congress and the state legislatures to develop more effective remedies for fourth amendment violations. ${ }^{136}$ In fact, the $\mathrm{Mc}$ Curry ${ }^{137}$ court read the Chief Justice's concurring opinion expansively and conjectured that one justification for "rendering habeas corpus unavailable" in fourth amendinent cases was that alternative remedies were still open to the petitioner. ${ }^{138}$ The section 1983 dannage remedy is an obvious alternative; it compensates the victim of an illegal search and seizure without the harmful effect of releasing a guilty felon and has a deterrent effect as well. ${ }^{139}$

(discussing the possible apphcation of Stone to fifth and sixth amendment claims). But see id. at 1146 (refusing to extend Stone to fifth and sixth amendment claims).

The Suprene Court repudiated this view of Stone, however, in Rose v. Mitchell, 443 U.S. 545, 560-61 (1979). The Court held that federal habeas corpus was properly invoked upon proof that racial discrimination existed in the process of grand jury selection, despite the fact that the defendants had been properly convicted in a trial free from constitutional error. Id. But see id. at 579 (Powell, J., concurring): Justice Powell, who authored the Stone opinion, argued in his Rose concurrence that as the prisoners had been found guilty at trial the collateral attack on an issue unrelated to guilt constituted an abuse of federal habeas corpus.

135. See, e.g., Bivens v. Six Unknown Named Agents of Fed. Bureau of Narcotics, 403 U.S. 388 (1971). In dissent, Chief Justice Burger stated, "Although 1 would hesitate to abandon it uutil some meaningful substitute is developed, the history of the suppression doctrine [the exclusionary rule] deinonstrates that it is both conceptually sterile and practically ineffective in accomplishing its stated objective." Id. at 415 (Burger, C.J., dissenting). See United States v. Janis, 428 U.S. 433 (1976). In Janis, the Court stated:

In the past this Court has opted for exclusion in the anticipation that law enforceinent officers would be deterred froin violating Fourth Amendment rights. Then, as now, the Court acted in the absence of convincing empirical evidence and rehed, instead, on its own assumptions of human nature and the interrelationship of the various components of the law enforcement systein. In the situation before us, we do not find sufficient justification for the drastic ineasure of an exclusionary rule. There comes a point at which courts, consistent with their duty to administer the law, cannot contimue to create barriers to law enforcenent in the pursuit of a supervisory role that is properly the duty of the Executive and Legislative Branches. We find ourselves at that poimt in this case. Id. at 459.

See also Rose v. Mitchell, 443 U.S. 545 (1979). In Rose, the Court refused to apply Stone v. Powell, 428 U.S. 465 (1976), to a federal habeas proceeding which alleged that the state discriminated against certain minorities in the selection of a grand jury. The Court concluded that "a claim of discrimination in the selection of the grand jury differs so fundamentally from application on habeas of the Fourth Amendment exclusionary rule that the reasoning of Stone v. Powell should not be extended to foreclose habeas review of such claims in Federal court." 443 U.S. at 560-61. Thus, the Court distinguished between a claim of racial discrimination on habeas and the minimal value of the exclusionary rule as apphed in habeas proceedings. Id. at 559-64.

136. 428 U.S. at 500-01 (Burger, C.J., concurring).

137. McCurry v. Allen, 606 F.2d 795 (8th Cir. 1979), cert. granted, 100 S. Ct. 1012 (1980) (No. 79-935).

138. 606 F.2d at 799.

139. See text accompanying notes 163-68 infra. The effectiveness of section 1983, however, is significantly limited by judicially imposed immunities and defenses. See note 168 infra. But see 


\section{B. Fourth Amendment Rights Not Enforced Under Stone.}

In addition to denying a federal forum to the victim of stateinflicted fourth amendment violations, Stone reduces the probability that a violation of the fourth amendment will be redressed. In Wolff $v$. Rice, ${ }^{140}$ a companion case to Stone, the state court had upheld the constitutionality of a search despite the fact that the search warrant the police used to gain entry to the petitioner's home was clearly imvalid. The Supreme Court, applying the "opportunity for full and fair litigation"141 test, refused to consider the merits of the claim. The imphication of Stone and Wolff is that as long as the accused has had a full and fair hearing in the state court, a federal court may not review the fourth ainendment claim even though the state court's decision is plainly wrong. ${ }^{142}$ Federal courts reviewing petitions for habeas corpus are thus limited to determining whether the petitioner had a full and fair opportunity to litigate his fourth amendment claim in the state court. Violators of fourtl ainendment rights may go unpumished and their victims unconipensated when state courts make erroneous determinations at suppression hearings or on appeal.

The continued need for federal review of fourth amendment claims is apparent in view of the limitations of Stone and in view of evidence that state court systems continue to make erroneous decisions on fourth amendment issues. In light of Stone, section 1983 is the only available way to achieve effective federal review of fourth amendment claims. ${ }^{143}$ Strict application of collateral estoppel to fourth amendment claims filed pursuant to section 1983 may foreclose all federal judicial remedies to the litigant.

\section{REMEdies For Fourth AMENDMENT VIOLATIONS}

An effective remedy for violations of the fourth amendment by state officials is necessary. Such a remedy should further two goals: first, it should deter future violations of the fourth amendment; second, it slould compensate the victim of fourth amendment abuse for his

Owens v. City of Independence, $100 \mathrm{~S} . \mathrm{Ct} .1398$ (1980) (a municipality is liable in damages under section 1983 when municipal officials violate constitutional rights). Thus, the Court may be in the process of withdrawing broad grants of immunity from section 1983 liability.

140. 428 U.S. 465,473 (1976).

141. Id. at $481-82$.

142. Holmberg v. Parratt, 548 F.2d 745, 746 (8th Cir.), cert. denied, 431 U.S. 969 (1977); see Hines v. Auger, 550 F.2d 1094 (8th Cir. 1977); Note, Habeas Corpus After Stone v. Powell: the "opportunity for full and fair litigation" Standard, 13 HARv. C.R.-C.L.L. REv. 521, 533-40 (1978).

143. See text acconipanying notes 123-24 supra. 
injuries. 144 Unlike the exclusionary rule, a section 1983 damage remedy would serve both objectives well - provided that access to the remedy is not barred by the operation of collateral estoppel.

\section{A. The Nature of the Fourth Amendment Right.}

The fourth amendment protects a person's privacy against unwarranted state intrusion. In Katz v. United States ${ }^{145}$ the Supreme Court established that the amendinent "protects people, not places." 146 That is, the fourth amendment protects a right personal to the individual, rather than a property right. This principle recognizes that an individual has qualities that are not derived in any way from the state, such as his "personality." Some aspects of personahty are public, but some are private. A primary function of law is to preserve those private aspects of personality froin undesired and unwarranted intrusion and disclosure. ${ }^{147}$ Thus, the fourth amendment forbids state intrusion imto the private aspects of personality by prohibiting unreasonable searches and seizures.

One commentator has noted two divergent views of the nature of the right that the fourth amendinent protects. ${ }^{148}$ This commentator asks "whether the amendment should be viewed as a collection of protections of atomistic spheres of interest of individual citizens or as a regulation of governmental conduct." 149 The choice may very well dictate the remedy that courts should use to prevent and redress violations of the fourth amendment.

Katz and other Supreme Court cases seem to support the view that the fourth ainendment does not merely require government officials to act in a reasonable manner, but also protects the right to personal privacy. ${ }^{150}$ Accordingly, a viable and effective renedy for fourth ainend-

144. The Court has recognized that monetary relief is a remedy available to the victim of an unconstitutional search or seizure. See Bivens v. Six Unknown Named Agents of Fed. Bureau of Narcotics, 403 U.S. 388, 395-97 (1971) (a violation of the fourth ameudment by federal agents gives rise to a cause of action for damages under that amendment). Bivens, who never weut to trial, never received the benefit of the exclusionary rule.

145. 389 U.S. 347 (1967) (electronic surveillance of a phone conversation im a public phone booth, without a proper search warrant, violates the fourth amendment).

146. Id. at 351 .

147. Note, Formalism, Legal Realism, and Constitutionally Protected Privacy Under the Fourth and Fifth Amendments, 90 HaRv. L. REv. 945, 985 (1977).

148. Amsterdam, Perspectives on the Fourth Amendment, 58 MinN. L. Rev. 349, 367 (1974).

149. Id. 367.

150. The Court has stated that the "basic purpose of [the fourth] Amendmeut . . . is to safeguard the privacy and security of individuals against arbitrary imvasions by governmental officials." Camara v. Municipal Court, 387 U.S. 523, 528 (1967), quoted in Michigan v. Tyler, 436 U.S. 499, 504 (1978). See Bell v. Wolfish, 441 U.S. 520 (1979), in which the Court dealt with pretrial detamees' fourth amendment objections to visual searches of body cavities and jail cells. 
ment abuse should not only deter and prevent official misconduct but also compensate the victim of an illegal search and seizure for the violation of his personal privacy.

\section{B. The Exclusionary Rule.}

The exclusionary rule is currently the major weapon used to enforce the fourth ainendinent. Nevertheless, in view of the nature of the right guaranteed by the fourth ainendment, the exclusionary rule is an inadequate remedy for violations of the fourth amendment. No substantial evidence indicates that exclusion of evidence effectively deters police misconduct. Moreover, the exclusionary rule does not compensate victims of fourth amendinent abuse. The guilty felon who is freed by operation of the exclusionary rule is "compensated," but this result is both socially and conceptually unacceptable, and does not compensate at all the truly innocent victim. ${ }^{151}$

1. The Deterrent Effects Are Outweighed by Social Costs. The Supreme Court has stated that the primary purpose of the exclusionary rule is to deter law enforcement officers from engaging in forbidden conduct. ${ }^{152}$ The rule is calculated to prevent fourth amendment violations, not to redress injuries caused by such violations. ${ }^{153}$ And there is doubt that the rule is at all effective. Professor Oaks, who has compiled the most coinprehensive and often-cited empirical study ${ }^{154}$ of the effectiveness of the exclusionary rule, offers the following analysis:

[I]t is apparent that the principal current argument for the exclusionary rule is a factual one: exclusion of evidence obtamed by illegal means will deter law enforcement officials from illegal behavior. "It is a logical enough theory, impregnable in the library." But a factu-

Upholding the validity of such searches, the Court noted that the fourth amendment's test of reasonableness requires a weighing of the need for the search against the accompanying invasion of personal privacy. Id. at 559. This test differs from a generalized requirement of reasonable behavior on the part of government officials. See Pennsylvamia v. Mimms, 434 U.S. 106, 108-09 (1977); United States v. Brignoni-Ponce, 422 U.S. 873, 878 (1975). See also Delaware v. Prouse, 440 U.S. 648,654 (1979).

151. See, e.g., Bivens v. Six Unknown Named Agents of Fed. Bureau of Narcotics, 403 U.S. 388, 415-16 (1971) (Burger, C.J., dissenting) (noting that the exclusionary rule leaves an innocent victim of an illegal search and seizure without a remedy; it is therefore necessary to create a damages remedy).

152. Umited States v. Calandra, 414 U.S. 338, 347 (1974). Dissenting in Calandra, however, Justice Brennan posits that the rule promotes judicial integrity and popular confidence in the government by giving content and meaning to the guarantee of the fourth amendment. Deterrence is thus one objective served by the rule, but need not be the sole or primary goal served. Id. at 356-60 (Brennan, J., dissenting).

153. Id. at 347.

154. Oaks, Studying the Exclusionary Rule in Search and Seizure, 37 U. CH1. L. REv. 665 (1970). 
ally based rule that is probably the most important constitutional device for supervising criminal proceedings in state courts should have a more secure foundation than a theory that has never been tested. Yet today, more than fifty years after the exclusionary rule was adopted for the federal courts and almost a decade after it was imposed upon the state courts, there is still no convincing evidence to verify the factual premise of deterrence upon which the rule is based or to determine the limits of its effectiveness. ${ }^{155}$

Moreover, society incurs high costs when a guilty felon is released because the arresting officer has erred. ${ }^{156}$ The crime goes unpunished, haunpering the vindication of the state's criminal prohibitions. The felon is at large to repeat his criminal acts, perhaps with a feeling of impunity because of his successful encounter with the law. Furthermore, the public loses confidence in the judicial system when it observes criminals, clearly guilty, being set free on "technicalities." The operation of the rule may also encourage police misconduct. A police officer may be teinpted to misreport the facts surrounding the search and seizure to avoid operation of the exclusionary rule. ${ }^{157}$

The Supreme Court, in Stone $v$. Powell, ${ }^{158}$ demonstrated that it is willing to cut back on the exclusionary rule so that a viable alternative may be developed. ${ }^{159}$ Given the costs of the rule and its doubtful effectiveness, this decreased reliance is a logical objective.

2. The Exclusionary Rule Does Not Compensate. The exclusionary rule is calculated to prevent fourth amendment violations, but not to compensate the victims of such violations. ${ }^{160}$ In one sense, however, a guilty criminal whose conviction has been barred by the exclusionary rule is compensated for the violation of his fourth amendment rights:

155. Id. 671-72; see id. 678-701, 706-09. See also Spiotto, Search and Seizure: an Empirical Study of the Exclusionary Rule and Its Alternatives, 2 J. LEGAL STud. 243 (1973). Spiotto, a student of Professor Oaks, reaches the same conclusion as his mentor. For a critique of Spiotto's methodology and conclusion, see Critique, On the Limitations of Empirical Evaluations of the Exclusionary Rule: A Critique of the Spiotto Research and United States v. Calandra, 69 Nw. U.L. REv. 740 (1974). Professor Oaks also noted that there were severe problems with constructing a research method that would accurately demonstrate the efficacy of the exclusionary rule and that the results reached could therefore not be vouched for with a high degree of certainty. Oaks, supra note 154 , at 709.

One commentator has remarked that the data is so inconclusive that the exclusiouary rule should not be summarily abandoned on the strcngth of such empirical studies. Canou, Is the Exclusionary Rule in Failing Health? Some New Data and a Plea Against a Precipitous Conclusion, 62 KY. L.J. 681, 684-85 (1974).

156. See United States v. Janis, 428 U.S. 433, 448-49 (1976) (discussing the need for a deterrent against fourth amendment violations).

157. See Oaks, supra note 154, at 696-99.

158. 428 U.S. 465 (1976).

159. Id. at 500-01 (Burger, C.J., concurring).

160. United States v. Calandra, 414 U.S. 338, 347 (1974). 
he is set free. This form of redress is inappropriate for several reasons. First, as noted above, the social costs of the exclusionary remedy are high. Thus, the victim of fourth amendment abuse who is also a guilty felon is overcompensated. Second, although a crude sense of justice may dictate that a person should go free when his conviction is based on illegally obtamed evidence, the remedy provides no relief for imjury to the person's interest im personal privacy. ${ }^{161}$ Instead, the rule inerely tolerates the commission of a crime because of police error.

Moreover, for the innocent victim of a fourth amendment violation, exclusion of evidence provides no benefit; he presumably would have been acquitted regardless of whether any illegally obtained evidence had been discovered and admitted at trial. ${ }^{162}$ Similarly, the exclusionary rule does not benefit the victim of an illegal search that does not lead to an arrest, indictment, or trial. The injury to a person's interest in personal privacy reinains unredressed. In no situation does the exclusionary rule properly compensate the victim of an illegal search and seizure.

\section{Section 1983 Damage Action.}

The advantage of a civil damage action brought under section 1983 is that it can both compensate the victim of an illegal search and seizure and deter police misconduct. ${ }^{163}$ Because the fourth amendment protects an individual's right to personal privacy and security, ${ }^{164}$ a damage remedy is consistent with the nature of the right. The exclusionary rule, on the other hand, does not attack fourth amendment violations from the perspective of protecting privacy interests. Rather, it is "a judicially created reinedy designed to safeguard Fourth Amendment rights generally through its deterrent effect . . . ."165 Although prevention of fourth ainendment violations is clearly a worthy goal, any systein of justice should satisfy the equally important objective of providing compensation for victims of illegal police conduct. ${ }^{166} \mathrm{~A}$

161. See Newman, Suing the Lawbreakers: Proposals to Strengthen the Section 1983 Damage Remedy for Law Enforcers' Misconduct, 87 YALE L.J. 447, 449 n.6 (1978).

162. See Murphy v. Andrews, 465 F. Supp. 511 (E.D. Pa. 1979) (because he was acquitted, the defendant had no reason to appeal a denial of his motion to suppress; collateral estoppel was not apphed in his section 1983 damage action). See also Brinegar v. United States, 338 U.S. 160, 181 (1949) (Jackson, J., dissenting); Gottlieb, Fcedback from the Fourth Amendment: Is the Exclusionary Rule an Albatross around the Judicial Neck?, 67 KY. L.J. 1007, 1011 (1979); Newman, supra note 161 , at 449 . See note 151 supra.

163. Gottheb, supra note 162, at 1013; Newnian, supra note 161, at 453.

164. See text accompanying notes $145-50$ supra.

165. Stone v. Powell, 428 U.S. 465, 486 (1976) (quoting United States v. Calandra, 414 U.S. 338, 348 (1974) (emphasis added)).

166. See note 144 supra. 
fourth amendinent violation directly injures the individual. This injury must be compensated as would any other tort. Section 1983 is an effective mechanisin for compensation. ${ }^{167}$ In addition, it performs a deterrence function, because coinpelling tortfeasors to pay damages is likely to discourage tortious conduct.

The defenses to a section 1983 damage action must not be so expansive as to render the reinedy useless. ${ }^{168}$ Collateral estoppel is one technique for debilitating the section 1983 remedy. Preventing and correcting violations of the fourth ainendinent are goals far too impor$\operatorname{tant}$ to be hampered through the use of collateral estoppel.

\section{ConClusion}

The fourth amendment protects a fundamental personal right to freedom from certain government conduct. ${ }^{169}$ An effective mechanism for redress must exist for those persons injured by violation of this constitutional provision. Fourth amendment violations represent misconduct by the state and ultimately "threaten the vitahity of a systen of ordered liberty." 170 Congress has provided a powerful remedy for fourth amendnient violations through the enactinent of section 1983. Currently, however, the efficacy of the section 1983 reinedy is threatened by the application of collateral estoppel to section 1983 actions brought subsequent to state criminal proceedings. When a defendant has litigated his fourth amendment claims in a state suppression hearing, collateral estoppel bars federal review of his claim in all but the few cases in which the United States Supreme Court grants review.

For four reasons, collateral estoppel should not be applied under these circumstances. First, in enacting section 1983, the Forty-second

167. But see Carey v. Piphus, 435 U.S. 247 (1978), holding that without proof of actual injury, the plaintiff could recover only nommal damages in a section 1983 action in which he alleged a denial of procedural due process. The Court left open the possibility that a different measure of damages would apply if the constitutional violation were of a different nature, Id. at 258. See Note, Section 1983: An Analysis of Damage Awards, 58 NEB. L. REv. 580 (1979).

168. Most section 1983 defendants can raise good faith and reasonable belief in probable cause as defenses. See, e.g., Pierson v. Ray, 386 U.S. 547 (1967). Some section 1983 defendants, such as judges and prosecutors, have absolute immunity from section 1983 liability. Imbler v. Pachtnian, 424 U.S. 409, 420 (1976). See Butz v. Economou, 438 U.S. 478, 501 (1978) (fedcral officials should enjoy no greater zone of protection when they violate federal constitutional rules than do state officers; only a qualified immunity against constitutional claims exists for federal administrative officials). But see Owens v. City of Independence, 100 S. Ct. 1398 (1980) (a municipality is liable under section 1983 for constitutional violations committed by its officers). See generally Comment, Derivative Immunity: An Unjustifiable Bar to Section 1983 Actions, 1980 DUKE L.J. 568.

169. See text acconipanying notes 145-50 supra.

170. Newman, supra note 161 , at 447. 
Congress clearly contemplated that the federal courts would be the primary guardians of federal constitutional rights against erosion by the states. This policy of generous access to the federal courthouse should be implemented by permitting plaintiffs to bring section 1983 actions for constitutional violations free of the bar of collateral estoppel. Second, permitting issues of fact and law to be relitigated in a subsequent section 1983 damage action impacts minimally on the finality and integrity of judginents rendered im a state court. Judgments of acquittal or conviction are not attacked under a system that allows a defendant to pursue his action for damages in a later federal action. ${ }^{171}$ Third, the lack of the federal habeas corpus remedy because of Stone $v$. Powell ${ }^{172}$ throws a heavy burden of correcting fourth amendment infringements upon suits brought pursuant to section 1983. If collateral estoppel is applied uniformly to section 1983 actions that follow state court denials of motions to suppress evidence on fourth amendment grounds, the individual will be demed all opportumity to litigate his constitutional claim in a federal court.

Finally, the fundainental importance of the freedom from unreasonable searches and seizures and the madequacy of the exclusionary rule as a remedy compels the conclusion that an exception to collateral estoppel is warranted in a damage action brought under section 1983. The Supreme Court is dissatisfied with the exclusionary rule, as are most jurists. ${ }^{173}$ The section 1983 damage action is a superior remedy to the exclusionary rule; it inust not be made unavailable through rigid application of collateral estoppel principles. The collateral estoppel doctrine must be carefully applied "lest a blind adherence to it tend to defeat the even firmer established policy of giving every litigant a full and fair day in court." 174

David E. Nash

171. See text accompanying notes 102-08 supra.

172. 428 U.S. 465 (1976). See text accompanying notes 112-43 supra.

173. E.g., 428 U.S. at 500-01 (Burger, C.J., concurring).

174. United States v. Silliman, 167 F.2d 607, 614 (3d Cir. 1948). 